\title{
EDIPO REY, DE PIER PAOLO PASOLINI (1967). LA TRAGEDIA DEL HÉROE CLÁSICO GRIEGO Y EL INCESTO IGNORADO
}

\section{OEDIPUS REX, BY PIER PAOLO PASOLINI (1967). THE HERO OF CLASSICAL GREEK TRAGEDY AND INCEST IGNORED}

José Rodríguez Terceño: Universidad Complutense de Madrid (España) josechavalet@gmail.com

\section{CURRÍCULUM VITAE}

Doctorando en Comunicación Audiovisual por la Universidad Complutense de Madrid (España). Licenciado en Comunicación Audiovisual. Miembro de Fórum XII de Comunicación y Relaciones Públicas y de la SEECI (Sociedad Española de Estudios de la Comunicación Iberoamericana)

\section{RESUMEN}

La práctica sexual incestuosa, ya fuera está explícita o no - practicada o no-, ha acompañado al hombre desde sus orígenes. La prohibición, el horror, la indiferencia o la regulación social de tales prácticas han sido muchas de las formas mediante las cuales el hombre ha hecho frente al sexo incestuoso, pero no es hasta la aparición de los textos artísticos cuando comienza a cuestionarse y reflexionar sobre el incesto. Ya sea a través de textos mitológicos (el mito de Edipo), de tragedias clásicas griegas (Sófocles), o de obras cinematográficas (Pasolini), el hombre reflexiona sobre el amor y el sexo incestuoso, como un mecanismo más para alcanzar una felicidad que, en el ser humano, siempre es finita. 
Edipo - Yocasta - Hijo - Incesto - Crimen - Culpa - Castigo

\begin{abstract}
The sexual incestuous practice, already out it is explicit or not - practised or not-, has accompanied the man from your origins. The prohibition, the horror, the nonchalance or the social regulation of such practices have been many of the forms (ways) by means of which the man has faced to the incestuous sex, but it is not up to the appearance of the artistic texts when one begins to question and think about the incest. Already be across mythological texts (the myth of Oedipus), of classic Greek tragedies (Sophocles), or of films (Pasolini), the man thinks about the love and the incestuous sex, as one more mechanism to reach a happiness that, in the human being, always is finite.
\end{abstract}

\title{
KEY WORDS
}

Oedipus - Jocasta - Son - Incest - Crime - Guilt - Punishment

\section{ÍNDICE}

1. Introducción, definición de incesto y aspectos a considerar

2. Metodología y objetivos

3. "Edipo Rey" de Pier Paolo Pasolini (1967). La tragedia del héroe clásico griego y el incesto ignorado

4. Conclusiones

5. Bibliografía 


\section{Introducción, definición de incesto y aspectos a considerar}

Las prácticas incestuosas entendidas como acciones que tiene lugar dentro del grupo, tribu o comunidad, y que interrelacionan a sus miembros, incluidas las prácticas sexuales incestuosas, de una forma $u$ otra, ya sea desde una perspectiva antropológica o mitológica, han acompañado al hombre desde sus orígenes. Es por ello, que siguiendo diversos motivos o canales, se establecieron pautas y reglas para la regulación de las prácticas incestuosas, especialmente aquellas que mayor impacto podían tener dentro del grupo, como son las acciones de producción (trabajo) y las alianzas matrimoniales entre sus miembros. Muchas de esas normas o pautas de regulación fueron perdurando en el tiempo y han permitido observar y estudiar desde diferentes disciplinas, el origen y la ordenación de las prácticas incestuosas.

Gracias a ello podemos encontrarnos en nuestro tiempo con diversos enfoques sobre el incesto, que atañen tanto su práctica o su total indiferencia ante ella, así como su prohibición y posterior horror creado en torno a un mitológico tabú. Estos estudios provienen de disciplinas diferentes entre si, como lo son la antropología y la psicología (teoría psicoanalítica sería más correcto decir), que pueden provocar controversia si no se tiene en cuenta que todos los estudios terminan ofreciendo soluciones que no se contradicen o anulan entre sí, más bien todo lo contrario, nos devuelven múltiples soluciones ante una misma circunstancia, el sexo incestuoso.

Es por todo ello, que no encontraríamos una definición global de incesto que satisficiera a todas las perspectivas que sobre el incesto existen, por lo que para nuestro breve estudio, necesitaremos una definición que nos sirva como punto de partida y con la cual intentaremos analizar el enfoque, representación y reflexión que 
Nuestra definición de incesto que proponemos es la siguiente: todo aquel establecimiento o práctica de relación sexual, dentro del grado que sea, entre personas que comparten una relación previa basada en alianzas biológicas o consanguíneas dentro de una ascendencia o descendencia directa o indirecta. Quiere ello decir que dejamos al margen, que no fuera, las relaciones de parentesco establecidas por enlaces matrimoniales, para centrarnos en las relaciones sexuales (de carácter sexual, que no es exclusivo de la práctica del acto mismo, pues la relación sexual incestuosa puede darse de múltiples formas, no siempre explicitas, pero con un alto carácter erótico) y las manifestaciones de las mismas, aunque estás se den entre personas cuyo grado de afinidad biológica o consanguínea acontezca de una forma muy indirecta y alejada dentro de la estructura genealógica de ascendencia o descendencia.

Una vez considerado lo anterior, hemos de tener en cuenta que el texto con el que trabajamos, la película de Pasolini, está basado en una obra pre-existente, la tragedia "Edipo Rey" de Sófocles, que a su vez se basa en otro texto, el mito de Edipo, esta vez heredado de la tradición mitológica griega, probablemente de forma oral o a través de representaciones pictóricas. Hemos de tener en cuenta que los textos se centran en la figura del rey tebano Edipo, a quien los dioses castigaron condenándole a asesinar a su padre y yacer con su madre, ante su desobediencia, ante su intento de no conocer la verdad y querer forjar su propio camino ajeno a los designios divinos. Son el parricidio (que es a su vez un magnicidio) y el incesto los dos núcleos fundamentales de los textos, cuyas implicaciones afectan a personajes diferentes, por un lado a los protagonistas Edipo y Yocasta (también a Layo) y por otro el pueblo tebano. 
edípico, hemos de considerar que las desgracias del tebano no son ajenas a su destino, sino que estuvieron atadas desde sus orígenes al destino de su padre. Quiere todo ello decir, no son los crímenes de Edipo los causantes de los males que sufren todos los protagonistas de las obras, si no el crimen de Layo, el crimen del padre, quien condena a todos desde el comienzo. Lo que no se suele contar acerca del mito de Edipo, es que su padre Layo, cuando aún no había alcanzado el reino de Tebas, secuestro y abuso del joven Crisipo (según las versiones de forma consentida o no), hijo de Pélope, quien acudió al dios Apolo para que maldijera a Layo. Fue el oráculo de Delfos (consagrado a dicho dios, y que será también el encargado de sentenciar el destino de Edipo) quien vaticinó a Layo que su primogénito le asesinaría y yacería con su propia madre. El destino de Edipo está escrito mucho antes de su nacimiento, y será su arrogancia y orgullo los que le lleven a no querer escuchar al oráculo, que es su verdadero crimen.

Independientemente del mito de Layo, el verdadero crimen que tiene lugar en la tragedia de Edipo no es el incesto, del cual el propio protagonista huye después de escuchar el oráculo, sino el parricidio; pero tanto uno como otro, el asesinato del padre y el incesto, son consecuencias del verdadero crimen de Edipo, desoír y desobedecer a los dioses, es su orgullo, su hybris, la que le condena a matar a su padre y mantener relaciones carnales con su madre.

Ajena a estos detalles podemos encontrar también en la obra cierta carga psicoanalítica, el deseo y sentimientos amorosos del hijo hacía su madre, la envidia del padre y el enfrentamiento con su hijo que termina de forma trágica; pero sin embargo, una características aúna todos los crímenes cometidos en el texto, la ignorancia de estar cometiéndolos. Es cierto que Edipo asesina a un hombre en una encrucijada de caminos por su falta de respeto, pero no es consciente de estar 
mantener relaciones carnales con Yocasta, quien al igual que Edipo, desconoce su relación de parentesco.

La idea que prevalece es la del conocimiento y la ignorancia de los actos humanos frente a la felicidad del mismo. La ignorancia nos hace felices, y el conocimiento solo conlleva la culpa y el castigo, pero sin la verdad, no podríamos conocernos a nosotros mismos.

\section{Metodología y objetivos}

Nuestro planteamiento inicial es estudiar y analizar las formas de representación del incesto, de las relaciones sexuales, los elementos que el autor pone en juego, las influencias y la reflexión final que el autor propone, pero también la reflexión que nosotros podemos encontrarnos a la hora de analizar el film o a la hora de asistir a éste como meros espectadores, porque algunos de los aspectos más importantes de las representaciones que veremos a continuación no son tanto los elementos característicos del medio cinematográficos que se ponen en marcha en las películas, sino la manifestación misma del incesto, su tratamiento y su posterior discusión e influencia sobre los espectadores y por extensión sobre la sociedad.

Nuestra metodología será pues analizar el contenido del film, haciendo especial hincapié en algunos de los fragmentos o secuencias cuyos fotogramas podremos ver en el presente estudio, estudiando detenidamente el discurso (la forma o significante), y también la historia (el contenido o significado), para reflexionar sobre la representación que de las relaciones incestuosas propone el film, la forma en que se manifiestan y las implicaciones que tienen tanto dentro de las propias películas cinematográficas como en el propio espectador. 
incestuosas en el film persiguen ofrecer un texto claro sobre la reflexión de las prácticas sexuales, incestuosas en particular, pero por extensión sobre las prácticas de los seres en sociedad, siendo a su vez una profunda reflexión sobre el ser humano individual, sobre su forma de concebir su mundo interior y el que le rodea, donde los deseos y aspiraciones sexuales, así como sus prácticas no buscan otra cosa que el conocimiento de la verdad, ergo, de uno mismo.

El incesto y su práctica, son por tanto, acciones que tiene lugar dentro de la sociedad, y la reflexión sobre dicha práctica no es sino una reflexión sobre la sociedad misma, algunas veces más cerca del mundo interior del individuo, o del autor del film y del propio espectador si se prefiere, otras veces como estudio y meditación sobre las prácticas sociales y sus regulaciones.

\section{3. "Edipo Rey" de Pier Paolo Pasolini (1967). La tragedia del héroe clásico griego y el incesto ignorado}

El mito del rey Edipo y la tragedia que Sófocles nos legó, poseen un argumento de sobra conocido, cuya máxima recreación la encontramos en la adaptación más o menos libre que el genial poeta italiano nos dejó en su "Edipo Re" ("Edipo Rey"). Una versión pues, que no escapa del particular universo de Pasolini con el que impregnaba todas sus obras.

En ella no es difícil percibir cierto ejercicio de psicoanálisis, aunque lejos de querer ahuyentar demonios internos mal reprimidos, el cineasta nos devuelve una vez más, esta vez reflejado en imágenes, el amor que sentía por su propia madre, como ya habría hecho en alguno de sus poemas, baste como ejemplo: 
Aquello a quien el corazón bien poco asemejo.

Tú eres la única en el mundo que sabe, de mi corazón,

Lo que ha habido siempre, antes que ningún otro amor.

Eres insustituible. Por esto está condenada

A la soledad la vida que me has dado.

Por que el alma está en ti, eres tú, pero tú

Eres mi madre y tu amor es mi esclavitud..."

(Citado por Antonio Monclus, pág. 18)

Pero no solo a través de sus obras expresaba Pasolini su amor hacía su madre, también lo reconocía públicamente en una entrevista realizada en 1970, de quien decía que su presencia física, su manera de ser, de hablar, su discreción y su dulzura, subyugaron toda la infancia del poeta. "Yo he creído mucho tiempo que toda mi vida emocional y erótica estaba determinada exclusivamente por esta pasión excesiva, que yo tenía incluso por una forma monstruosa de amor" (Pasolini citado por Monclus, pág. 19). Pero la película no es solo una recreación del fuerte complejo de Edipo que sufría el propio cineasta, la recreación que del mito y tragedia edípica que Pasolini nos ofrece, nos sitúa en el centro mismo de la inocencia y la culpabilidad del saber, de las acciones humanas para escribir su propio destino y como nuestro pecados vuelven a cruzarse en nuestras vidas, quizás no de forma idéntica, pero si con la misma intensidad, una fuerza que no nos abandona incluso cuando se quiera ignorar la realidad como el propio Edipo intenta cuando se automutila al sacarse los ojos.

La película por lo tanto, nos ofrece una visión personal de los sentimientos y emociones del autor, pero al mismo tiempo, una representación de las relaciones sexuales, y concretamente de las incestuosas, que llegan hasta nuestros días. El texto presentado por Pasolini se puede dividir perfectamente en tres partes claramente diferenciadas pero al mismo tiempo conectadas entre sí; una primera parte es la 
segunda parte que recrea la adaptación de la tragedia de Sófocles (donde al igual que el escritor clásico deja un tanto de lado las apariciones divinas propias del mito), y una última parte que nos devuelve a la época actual en la que se produce y rueda el film para mostrarnos el final de Edipo - Pasolini adulto-
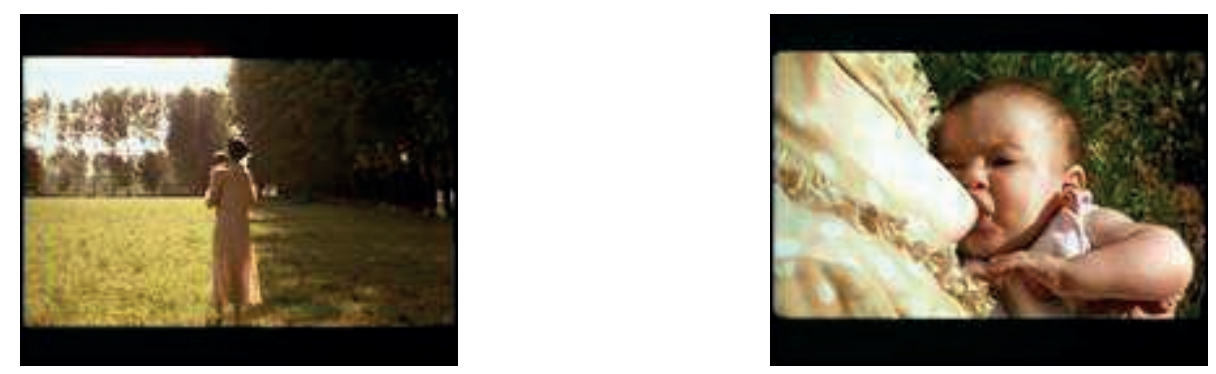

Durante los primeros minutos asistimos al nacimiento del joven Edipo, aunque es más cierto mencionar que al joven niño no se le otorga nombre, por lo que la identificación con el propio autor de la obra es algo más estrecha (la correlación más directa entre las tres etapas de Edipo que vemos a lo largo de la película la encontramos en las dos partes siguientes precisamente por estar encarnado el personaje por el mismo actor, Franco Citti). La representación del Complejo Freudiano da comienzo cuando nace la conciencia del joven niño, y a partir de ahí se nos presenta a los tres agentes que intervienen en el proceso, es decir, al niño, a la madre y al padre.

La conciencia del joven Edipo tiene lugar en un prado de sauces, a través del amamantamiento que refleja el estrecho lazo que lo une con su madre. La utilización de planos subjetivos desde la posición del niño permiten apreciar un poco mejor el proceso de toma de conciencia, así la cámara se mueve incesantemente siguiendo las figuras femeninas de su madre y sus amigas que corren por el césped, o de los inmensos sauces que rodean el prado. Es una toma de conciencia de la realidad, y 
del alimento proporcionado por esta. $\mathrm{Y}$ es en ese mismo acto donde comienzan a representarse los tres agentes de las teorías freudianas, pues podemos contemplar al niño por primera vez unido a su madre, en el que puede ser quizá el acto más directo de sexualidad, alimentarse del otro, en este caso de la madre. Y es la madre, otro personaje, al igual que el padre militar que aparecerá más adelante, sin nombre, la primera que nos devuelve la mirada y su expresión refleja claramente la dulzura pero también el daño que los lazos de amor entre ella y su hijo pueden llegar a ocasionar.
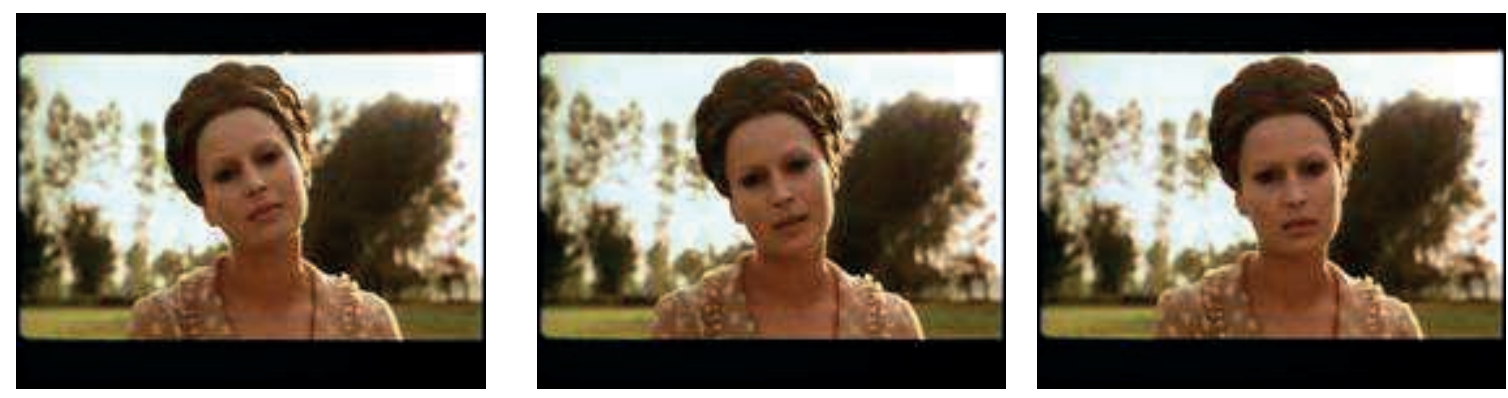

Ya en estos primeros planos podemos observar varias características que se repetirán a lo largo del film, especialmente cuando los personajes involucrados en la relación incestuosas se miren entre ellos; por un lado la mirada a cámara, apelando al espectador pero al mismo tiempo al propio Pasolini, sabedor de estar, junto al espectador, detrás en todo momento. Es muy frecuente que durante todo el film los personajes miren directamente a la cámara, que no hace otra cosa que subrayar esa vinculación directa entre los propios personajes y nosotros mismos. Por otro lado, aparece el tema musical principal de la película (el otro el una música alegre, festiva que suena en un par de ocasiones, durante los créditos iniciales y durante la fiesta a la que asisten los padres del niño). La música, en su mayoría instrumentos de viento, refuerza el carácter trágico de la representación, produciéndose un camino descendente pero a la vez más profundo hasta quedar reducidos todos los 
sabedor de sus últimos instantes de vida.

Además, los personajes femeninos de la película, la madre del Pasolini niño, Mérope y Yocasta, parecen intuir con su mirada el destino y final trágico que les espera a los personajes implicados en la relación incestuosa, a ella misma en el caso de la madre (Yocasta), al padre tiránico y al propio Edipo (Pasolini); del mismo modo que Mérope se despide entre lágrimas de su joven hijo cuando éste parte al oráculo de Delfos, intuyendo el destino que le espera, no tanto porque dicho camino le lleve a un final trágico como pueda ser la muerte, que lo es, sino porque la empresa principal del viaje a Delfos es buscar la verdad y esa no es otra que revelar que Mérope no es la verdadera madre de Edipo, perdiendo del mismo modo que con la muerte a su hijo más querido (que aunque no era suyo fue criado como el primogénito).
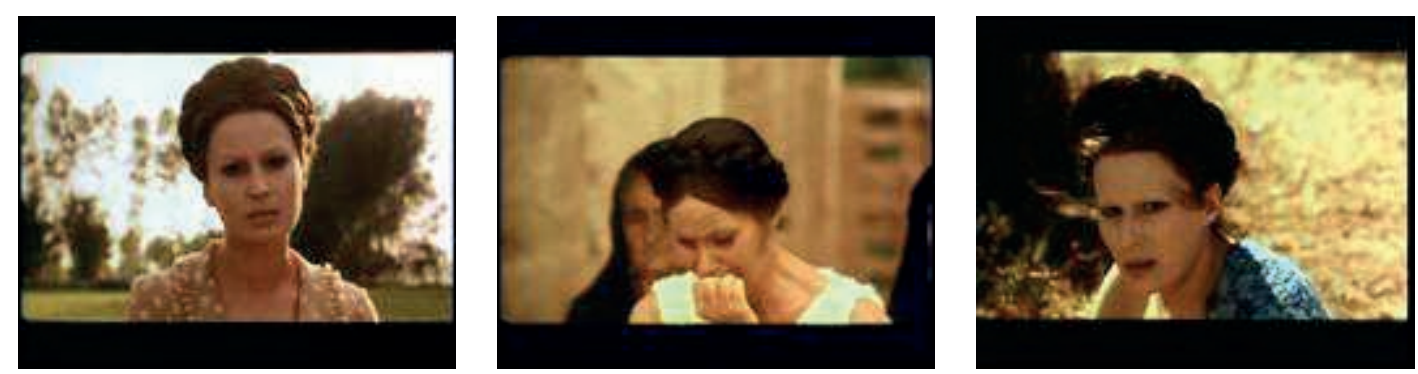

Antonio Monclus nos dice sobre el padre de Pasolini que "era un oficial de carrera, y con una fuerte mentalidad nacionalista, hombre de derechas que incluso había aceptado el fascismo, [...], era un buen representante del símbolo del padre freudiano, tiránico, autoritario, y egoísta" (pág. 21). Y el padre freudiano que representaba el padre de Pasolini aparece en el film, seguidamente después de que la madre alimentara al niño, estrechando sus lazos, para manifestarse como el tercero dentro del triángulo del complejo edípico, que lejos de comportarse como suele ser 
perdedor en su lucha por hacerse con el amor de su mujer, y por ello tomará la decisión de acabar con la vida de su hijo (algo que no logra, no porque seguidamente Pasolini nos sumerja en la recreación del mito griego, sino porque no se nos muestra hasta el final del film, el trágico destino del adulto y ciego Edipo-Pasolini).
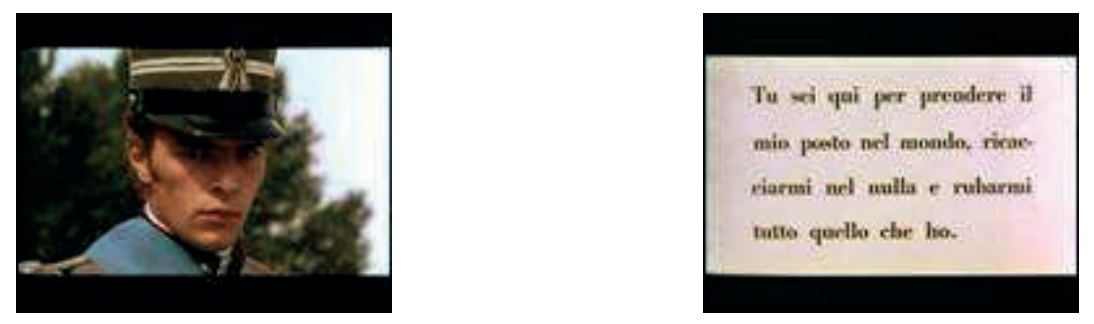

El padre militar le dice al niño, pero al mismo tiempo a nosotros: "Estás aquí para ocupar mi puesto en el mundo, y enviarme a la nada y robarme todo lo que tengo; ella será lo primero que me arrebates, la mujer que amo. De hecho, ya me estás robando su amor". Convendría ahora señalar algunos aspectos, muy resumidos, del famoso Complejo de Edipo desarrollado por Freud; dicho complejo se desarrolla durante la fase fálica del niño, entorno a los 4 ó 5 años, cuando advierte de las diferencias físicas que dejan de identificarle con la madre, convirtiéndose ella en el objeto de deseo, y creyendo ser el mismo, el niño, el objeto de deseo de su madre (debido a la atención que ella misma le presta). Pero surge entonces la prohibición sobre ese objeto, a través de la figura y la palabra del padre, el tercero, el Otro. Comienza entonces el niño un proceso que le lleva a luchar por su madre, exhibiendo su pene, intentando usarlo de manera agresiva, al mismo tiempo que comienza a sentir rechazo por la figura materna que le impide alcanzar el objeto de deseo. Pero para evitar el objeto, comienza a conocer físicamente las consecuencias de la trasgresión, es decir, de la posesión del objeto de deseo, principalmente cuando se da cuenta de que la fisonomía de las niñas es diferente, no tienen pene, han sido castradas por incumplir la prohibición del padre. Así, la represión interna del deseo 
controlada, eliminando poco a poco el rechazo y la culpa por el deseo de eliminar al padre para dejar paso a la admiración, a la identificación con él, y la estructuración correcta de su propia personalidad. No pretendemos defender la universalidad del complejo freudiano, porque ya algunos estudios antropológicos se han encargado de ello (remitimos al libro de Fox citado en la bibliografía), ni tampoco declarar que la represión del complejo conlleve siempre una buena estructuración de la personalidad, algo que veremos mejor en el film posterior de Bertolucci. Así pues, la primera parte del film nos pone de manifiesto el proceso psicológico edípico que sufrió el propio cineasta, representando las figuran genéricas del complejo freudiano, como base de la posterior evolución del protagonista, en este caso, del propio Pasolini, porque los problemas psicoanalíticos poco afectan a las acciones del joven Edipo clásico.
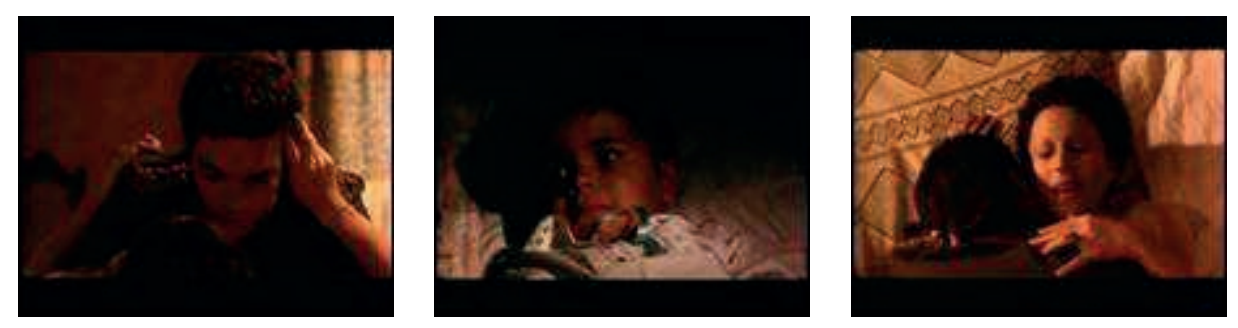

Así pues, Pasolini nos ofrece en imágenes el momento del acto o escena primordial, primaria, es decir, el acto sexual de los padres presenciado por el hijo, que no es necesario que asista a él, bastaría con oírlo o incluso imaginárselo para poner en marcha todo el proceso freudiano de represión.

La representación del acto sexual entre los padres, que no se muestra de forma explícita, como no lo serán ninguno de los encuentros sexuales entre Yocasta y Edipo, posee ya unas características que se repetirán en los posteriores encuentros entre madre e hijo, a los que luego aludiremos. Pero se nos presenta ya, en estos 
de asistir, estarán mediadas por la madre y por el hijo, dejando la figura paterna de lado, en el caso de Layo, asesinándolo. Es entonces cuando el padre freudiano decide separar al hijo de la madre, y entramos así en la recreación de la Grecia prehistórica, en la que tendrá resolución la relación incestuosa que de momento solo se ha manifestado en nivel psicológico, una dimensión que en las dos partes siguientes del films el propio autor dejará de lado para manifestar sus verdadero deseo en la representación de la tragedia.
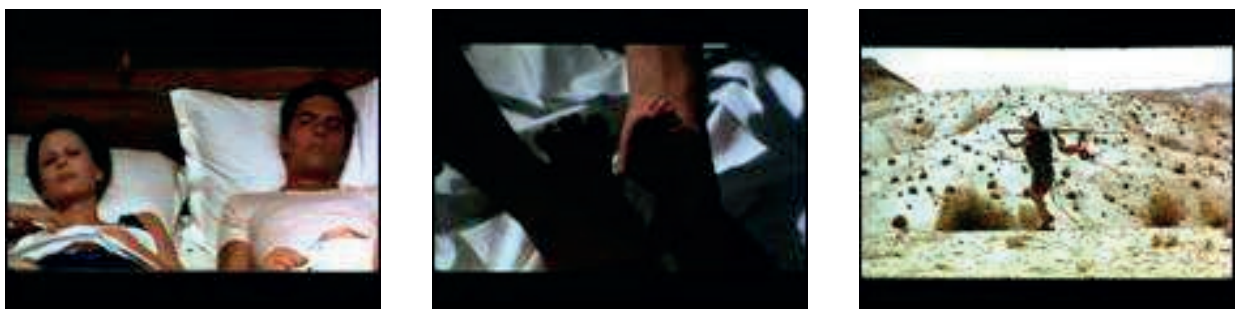

Antes de entrar de lleno en la relación incestuosa mantenida entre madre e hijo, conviene señalar que Pasolini desarrolla una puesta en escena donde no prevalece "la ilustración de la teoría psicoanalítica, por ejemplo a través de la referencia al mito, sino la contigüidad de los dos discursos y su contaminación: en el film, el psicoanálisis altera el mito y el texto de Sófocles, cuando por ejemplo, Edipo llega ante la esfinge, ésta no le propone resolver un enigma, sino arrojar luz sobre su propio secreto" (Silvestra Mariniello, pág. 288). Supone entonces la obra evitar "la apropiación del mito por parte de la burguesía; actúa en el plano de la sexualidad, ausencia de diálogos, el ritmo, la luz, los sonidos y los objetos inscriben la tragedia fuera de la moral moderna. Aquí no hay nada que forme parte del fondo representar la 'verdad histórica'- sino que todo está en primer plano y todo se mezcla: los rostros contemporáneos, el mito, las músicas procedentes de diversas culturas, las máscaras, y los objetos pertenecientes a momentos históricos diferentes, además de a mundos distintos. Es una prehistoria caprichosa y onírica" (Mariniello, 
planteados en las tres partes del film, afectaran de forma directa al modo de representar la relación incestuosa que se da entre madre e hijo, siempre sin escapar del universo particular del propio cineasta, el cual, ante todo, pretende reflejar "el contraste entre la total inocencia y la obligación de saber; no hacen a Edipo un intelectual" (Pasolini citado por Mariniello, pág. 291). ¿Cómo se manifiesta entonces la relación incestuosa?
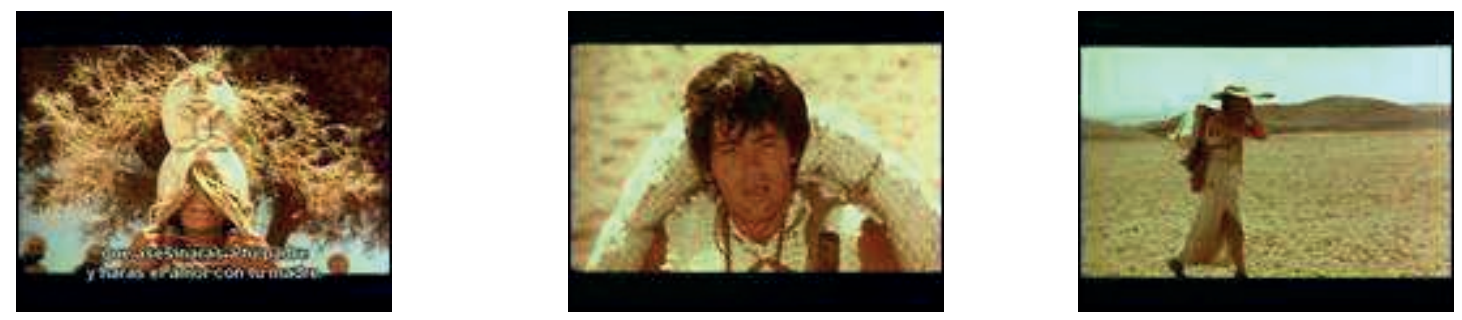

En primer lugar, existe en el personaje de Edipo, y por extensión creemos que en la sociedad de la Grecia prehistórica que nos pone en escena Pasolini, una conciencia moral, en primer lugar de culpa, y en segundo lugar de la inmoralidad de ciertos actos, ya sean estos de carácter sexual o no. Es por ello que Edipo huye del destino vaticinado por el oráculo de Delfos, pues antes que nada no quiere asesinar a su padre ni mantener relaciones con su madre. Es un destino, y unos actos, marcados por un ser superior al hombre que los hacen insalvables, se han de cumplir por mucho que su protagonista se empeñe en huir de ellos; y en este caso en concreto, es la huida de Pólibo y Mérope, la que precipita los acontecimientos que el oráculo le destino.

Pero es destacable que Edipo pretende huir de los mismo, es decir, ni desea la muerte de su padre, ni tampoco yace con su madre, por quien ni siquiera se manifiesta el mayor de los deseo libidinosos, salvo el afecto que un hijo pueda expresar por su madre, pero aquí, el cineasta utiliza planos que ponen de manifiesto la unión, no 
protagonistas desconocen los lazos que les unen, como podemos ver aquí:
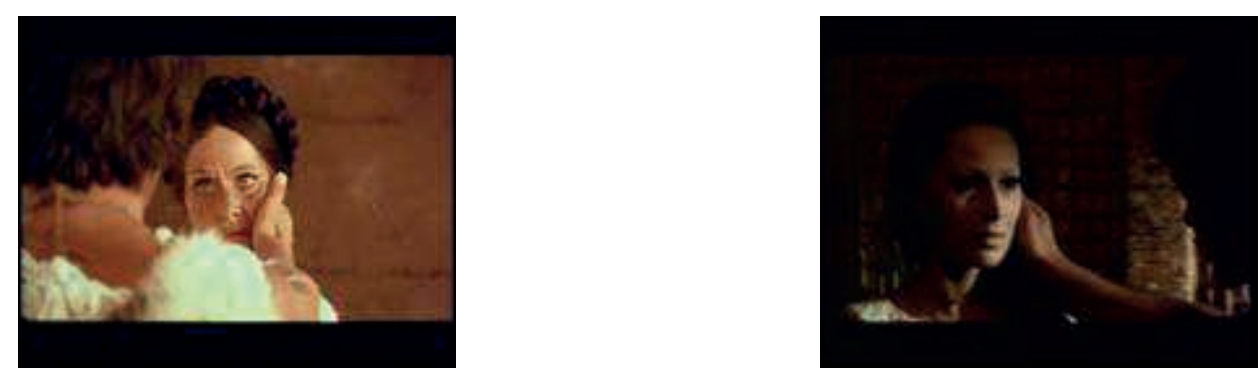

No existen los rostros de ambas mujeres deseo sexual alguno, si no más bien ternura por el ser amado, aunque de dos formas diferentes, como hijo y como esposo, pero no dejan de tener relación que las caricias que se profesan los personajes durante la recreación del mito son muestras que van más allá de la pulsión sexual incestuosas; incluso en Yocasta, cuya dulzura intenta aconsejar a Edipo que no siga insistiendo en descubrir la verdad, una verdad que ya es conocida por la mujer, que la acepta hasta que la culpa puede con ella.

La hazaña de Edipo de dar muerte a la Esfinge que acecha a la entrada de Tebas, posibilita la unión entre Yocasta y su hijo; pero dicho acontecimiento no pone otra cosa de manifiesto que la carencia intelectual de Edipo, reflejado no solo en la ausencia del enigma el mito, sino también en el orgullo característico del héroe trágico griego ya en la obra de Sófocles, pero también en la ignorancia de comprender la verdad cuando ya todos la conocen y pretender evitársela para que el funesto destino no se cumpla. 

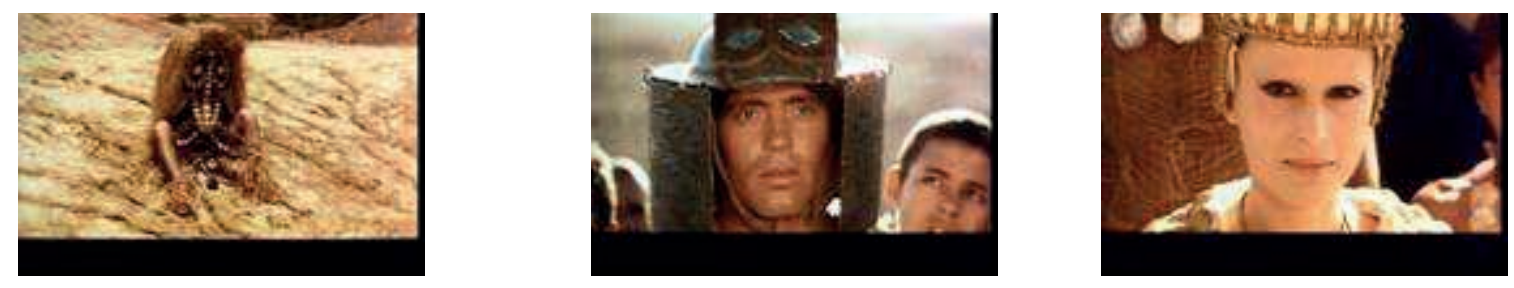

La muerte de la Esfinge deja paso al encuentro visual entre Edipo y Yocasta, con primeros planos que miran directamente a cámara, y en los que no se atisba ningún rastro de duda o temor entre los dos personajes, todo lo contrario, existe un primer interés sexual entre los dos personajes que desconocen sus lazos de parentesco consanguíneos, un interés y un deseo, mezcla de sexualidad pero también de ternura y de sentimientos cariñosos que no dejan de estar presentes en los diferentes encuentros que mantienen Yocasta y Edipo, carentes de palabra o dialogo alguno, dejando paso a las miradas, los gestos y las caricias, reflejo del amor que se sienten el uno por el otro. No hay conocimiento de estar cometiendo un acto pecaminoso, el incesto, pero su proyección afecta al pueblo tebano, la peste está diezmando la población, y el pueblo acude a pedir consejo de Edipo. "Mirar dentro de si mismo lleva más allá del yo, más allá de la psicología del sujeto, hacía la sociedad y la historia. La cuidad sufre, la gente muere, la comunidad necesita la 'conciencia' de Edipo. El mito, que introduce esta dimensión social, se convierte en el médium del posible encuentro entre dos filosofías que eran consideradas incompatibles: el marxismo y el psicoanálisis" (Mariniello, pág. 292).

Nuevamente se deja de lado de forma intencionada los designios divinos de Layo, que aunque mencionados, no forman parte importante de la historia, para centrarnos en las desgracias de Edipo. Cumpliendo con los requisitos de todo héroe griego clásico, Edipo es un personaje de alta nobleza, un rey, que peca de orgullo, desafía los designios de los dioses y yerra en su intento por alcanzar la verdad y solucionar los problemas. Porque, como ya veníamos anticipando, no es la relación incestuosa la 
acabar con la peste que asola la cuidad es castigar al culpable del asesinato de Layo, en ningún momento se menciona el acto incestuosos como causante, sino más bien como una forma más de castigo por el crimen cometido sobre el antiguo rey tebano.

En la introducción a las “Tragedias” de Sófocles (Gredos, Madrid, 1998), José S. Lasso de la Vega se cuestiona sobre el delito de Edipo: “¿Cuáles son los hechos punibles de Edipo?¿Satisfacción de sí propio, excesos en su reacción, sin ser dueño a contenerse, ante Tiresias o Creonte, o es la suya una hybris post eventum? ¿O no hay culpa y la hamartia (trágico error cuando el héroe intenta hacer lo correcto en una situación en que lo correcto simplemente no puede hacerse), de que habla Aristóteles (en su "Poética"), es simplemente su ignorancia? (págs. 82, 83). Para responderse: “El de Edipo no es un error o una cuantía de errores, sino un 'sistema de errores', capaz de organizarse automáticamente y que se realiza, particularmente, a través de la ironía omnipresente" (pág. 84).

El incesto que se da entre Yocasta y Edipo, es un acto incestuoso ignorado, a excepción de los dioses y de sus oráculos, pero los protagonistas ignoran dicha relación entre madre el hijo, incluso el pueblo lo ignora, el verdadero crimen sin justicia que asola la cuidad es el asesinato de Layo. Es más, cuando Edipo está cerca de resolver el enigma de su destino, cuando enfrenta a los dos pastores, uno de Layo y el otro de Pólibo, la discusión de cierra entorno al niño abandonado a su suerte en los parajes desérticos, como último recurso para descubrir al asesino del rey tebano, que propicia a su vez, el descubrimiento del verdadero lazo que une a Edipo con Yocasta. Pero, como el film nos pone de manifiesto, el acto incestuoso solo tiene consecuencias sobre los protagonistas que lo cometen, es decir, Yocasta y Edipo. La culpa, el delito de Edipo, no es el acto incestuoso, sino su arrogancia, su orgullo de querer construirse su propio camino caminando solo, intentar alejarse de la verdad 
quieren revelarse la verdad de su destino y la desgracia se aúna con su hybris en su lucha trágica por descubrir una verdad que finalmente le dejará ciego, porque "se le ha dado a conocer su propio destino, pero cerrando los ojos combate lo que sabe, no acepta la conciencia del mal que hay en él. Por eso debe vagar por los siglos condenado a la conciencia, pero sin poder ver el nuevo mundo que ha querido ignorar" (Mariniello, pág. 291). Así, sus crímenes sobre Layo y sobre su madre Yocasta perduran dentro de la oscuridad a la que se auto-condena cuando se mutila los ojos, pero libra finalmente a su pueblo de los males que el mismo trajo consigo.

El incesto entonces, es un crimen destinado a quienes lo ponen en práctica, en este caso a Yocasta y Edipo. Pero completando un poco más la estructura tripartita del complejo freudiano, afecta a los tres agentes que interviene, a saber: Layo, Yocasta, Edipo, o Pasolini, su padre y su madre. Si José S. Lasso de la Vega sostiene que "Edipo Rey es fundamental un documento religioso" por la tragedia escrita por Sófocles (pág. 83), también encontramos cierta repetición litúrgica en la representación de los encuentros sexuales que aparecen en el film, especialmente entre Edipo y Yocasta. Encontramos seis actos sexuales en pantalla, uno de ellos entre el joven padre militar y su esposa, y los restantes entre Yocasta y el propio Edipo.
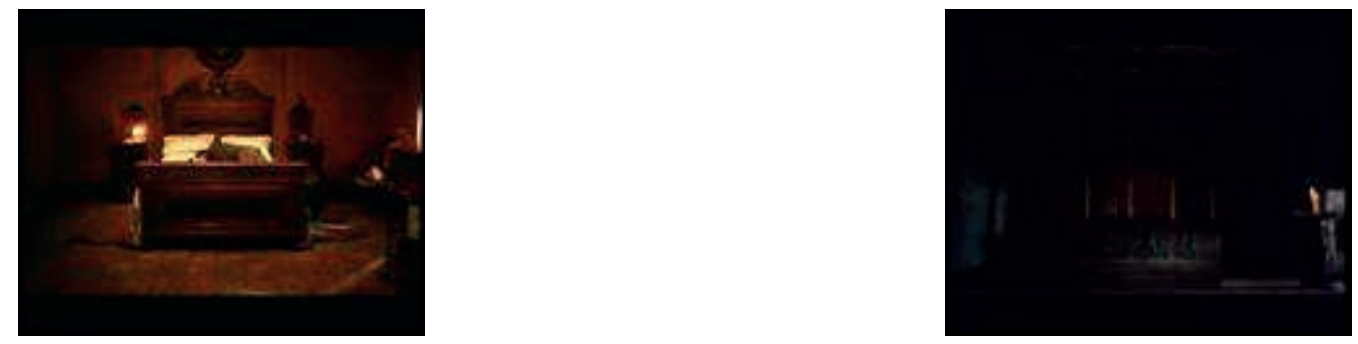

Antes de cualquier acto se nos presenta el lugar en el que tendrán lugar, dos instancias donde ocurrirán los acontecimientos más importantes de la trama 
encuentros sexuales entre madre e hijo en la representación del mito griego, y el castigo auto-infligido de Yocasta y Edipo sobre sí mismos. A partir de ahí, los encuentros sexuales, nunca explicitados en imágenes nos son ofrecidos siguiendo una cadencia de planos muy similar, pero en evolución según se van desarrollando los acontecimientos y los personajes van descubriendo la verdad. Existe cierto minimalismo en la utilización de planos, pero es una sencillez que se ve reforzada por la intensidad de las miradas y gestos de los protagonistas, así como la ausencia de dialogo. Encontraremos también la ausencia total de sonido alguno salvo los ruidos producidos por las dos personas que van a consumar el acto.
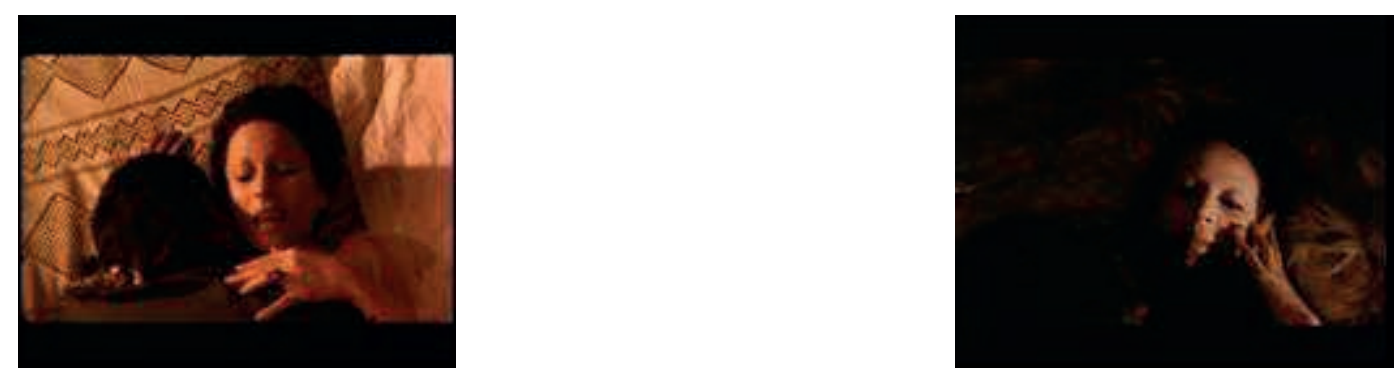

Pero el verdadero ritual lo encontramos en los encuentros directos entre Yocasta y Edipo, siempre desarrollados del mismo modo, solo interferidos por el desarrollo de los acontecimientos, algunos de ellos incomprensibles para los propios protagonistas, tanto, que en ocasiones se dejan al margen para expresar sencillamente el sentimiento que se sienten el uno por el otro, desconocedores de la verdad, de su acto incestuoso.
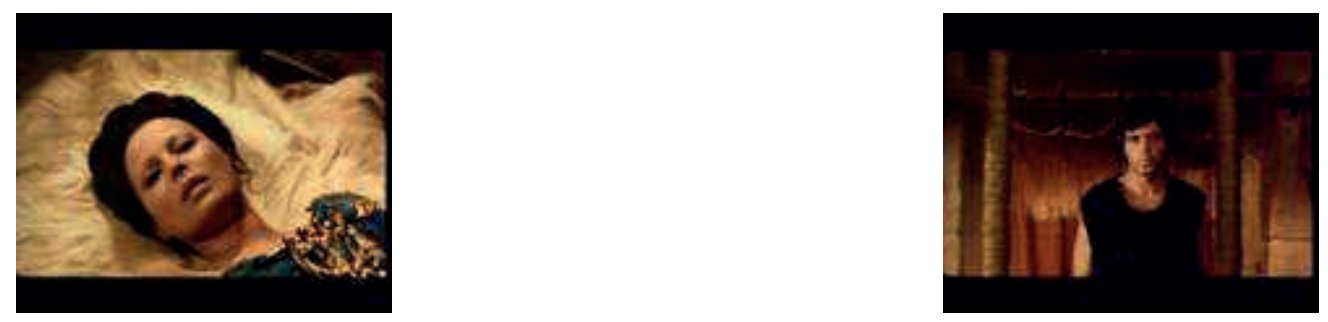

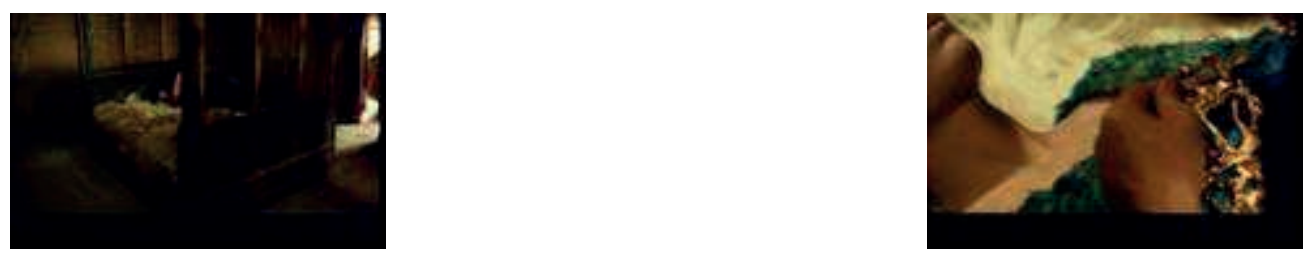

Presentado el lugar del acto, la cama de una dimensiones a tener en cuenta, y cuyo diseño con los barrotes en el cabecero y a sus pies nos harán creer que sus dos protagonistas, quienes dentro de la misma cama llevan a cabo un acto como tal, están presos de sus propias acciones, es decir, del incesto que sin saberlo están cometiendo. La mujer suele tomar una posición pasiva y es el hombre, Edipo, quien posee a la mujer, y en todos los encuentros, destacan por encima de todos dos características, la pasión con la que viven el momento y que tendrá su eclosión final en uno de los encuentros sexuales finales, pero son todos ellos igual de intensamente vividos; y por otro lado el desprendimiento del broche que guarda el cuerpo de la mujer, el cuerpo de la madre de Edipo, cuya presencia es constante, como salvaguarda de un encuentro incestuoso, advertencia de que no debe producirse el acto sexual pero que es desabrochado voluntariamente y por deseo de los dos protagonistas.
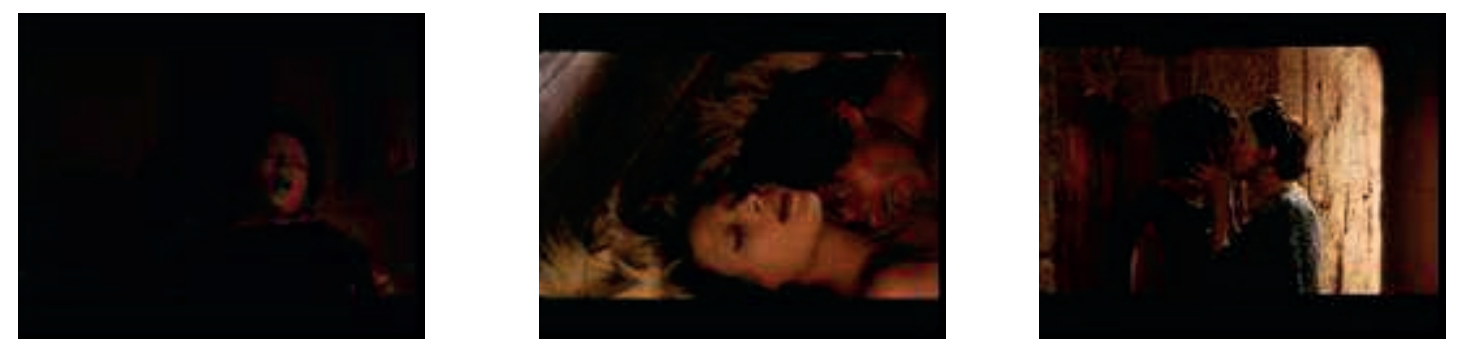

La pasión expresada en los encuentros nos devuelve el encuentro sexual entre dos personas que sienten un amor y una excitación reciproca, sin pena ni culpa alguna.

La culpa, los remordimientos en la relación entre Edipo y Yocasta no surgirá hasta que los acontecimientos de la resolución del crimen de Layo comiencen a llegar a 
aún lejos del acto incestuoso; la culpa comienza a asomar en ellos dos cuando todo parece indicar que Edipo fue el asesino de Layo, la misma persona que les ha puesto en contacto a ellos. El temor de haber asesinado a un hombre provocando la epidemia que asola su pueblo, a la vez que toma posesión carnal de la que fuera su esposa, y el sentimiento de culpa de yacer con el asesino de su marido, son los primeros reflejos que podemos presenciar en las imágenes, aún sin estar relacionados con el incestos ignorado por el momento.
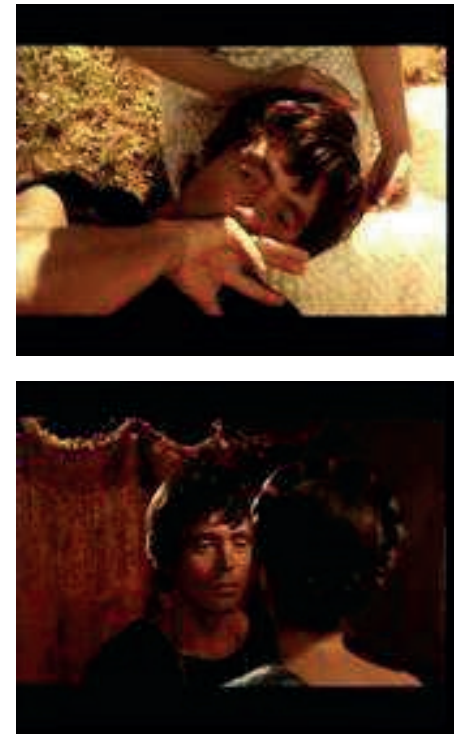
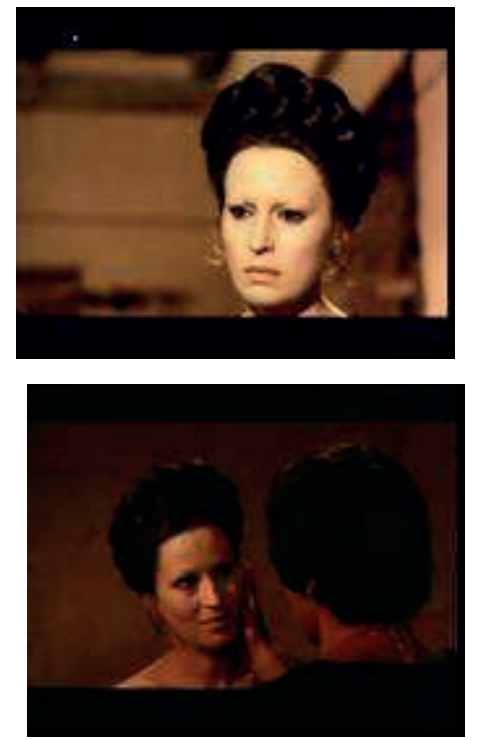

Pero estos son pecados contra los que se puede luchar y que no interfieren en los encuentros sexuales que nuestros protagonistas siguen consumando; en cambio es más difícil luchar contra el acto de yacer con tu propia madre o con tu propio hijo; cuando la obra comienza a desvelar la verdadera relación que existe entre Edipo y Yocasta, es entonces cuando la relación entre ellos comienza a verse afectada, y el descubrimiento no podría darse en otro lugar que donde se procede a la liturgia y ritual del encuentro sexual incestuoso, en la cama que comparten Edipo y Yocasta. 

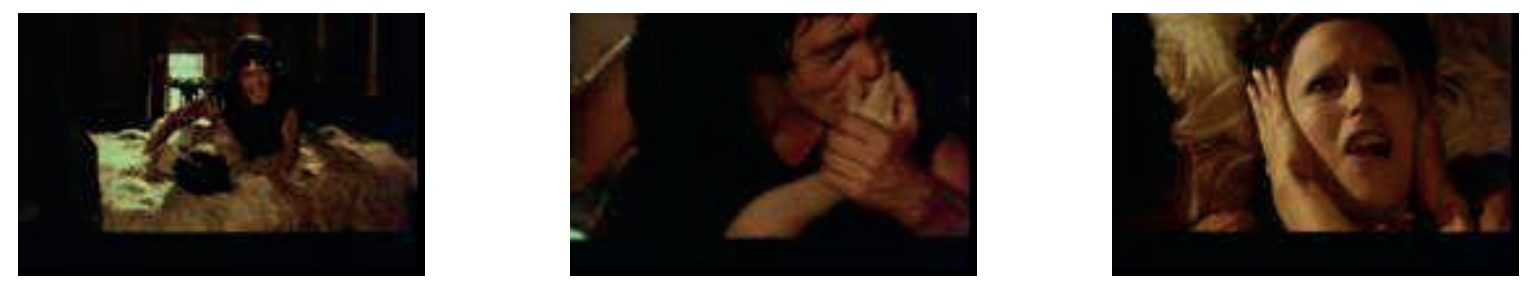

En ella, en la cama, la pasión antes exhibida en el deseo sexual estalla ahora en gritos ahogados que proclaman la verdad, que Edipo y Yocasta son madre e hijo. Pero es una verdad de la que Edipo intentó huir, contra la que lucho porque no se cumpliese tal y como vaticinaron los dioses, y una verdad que Yocasta no quiere oír.

No impedirá el descubrimiento de la verdad que se anulen los sentimientos que Edipo y Yocasta sienten el uno por el otro, no al menos hasta tener pruebas certeras sobre dicha verdad. $\mathrm{Y}$, aunque en su interior ya conocen esa verdad, la revelación de su relación de madre e hijo, consuman el acto sexual incestuoso por última vez, pues es deseo, el sentimiento que se tiene como amantes es más fuerte que el puedan tenerse por ser madre e hijo, una relación filiar que no se ha dado en mucho tiempo.

Los dos se entregaran al que sabe será su último encuentro sexual, ahora si, plenamente incestuoso.
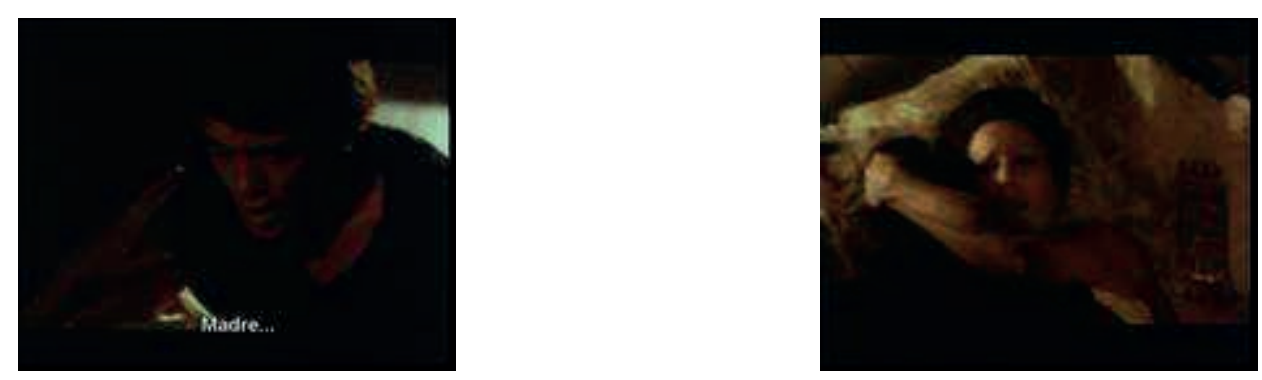

El propio Edipo, quien antes se refería a Yocasta como 'amor mío', la llama ahora y por primera y última vez 'madre', y tiene lugar el acto sexual, presenciado en todo 
guardaba el cuerpo de la mujer-madre del contacto incestuoso del (marido) hombrehijo.

Hemos dejado de lado una escena crucial para las teorías freudianas, también presente en la obra de Sófocles, en la que la propia Yocasta le dice a Edipo: ¿Por qué te horroriza tanto la idea de ser el amante de tu madre? Muchos han hecho el amor con su madre en sueños, ¿y viven horrorizados por ese sueño?". Estas palabras, de una importancia capital para Freud, pues le darían pie para expresar que en el inconsciente de todo hijo está reprimido el deseo de poseer a su madre, que solamente sale a la luz en los sueños, nos sirven a nosotros para defender la idea del incesto ignorado, es más, de la ausencia total de incesto ante el desconocimiento de quienes lo llevan a cabo, en este caso, Edipo y Yocasta.

Edipo es un hombre que lucha contra los designios de los dioses, él quiere escribir su propia historia, y es su orgullo la que le lleva a matar a Layo (para lo cual quizás tendría motivos dada la soberbia del rey tebano), y a alcanzar la terrible verdad que esconde el asesinato de éste. Pero tampoco es un hombre que desee a su madre, todo lo contrario, sabedor del vaticinio de Delfos, huye de la que cree su madre para caer en brazos de la bella Yocasta. Una mujer, la reina de Tebas, que siente el mismo deseo sexual por el joven Edipo, a quien incluso llega a amar tras la muerte de su marido. El que sea la propia Yocasta quien pronuncie las palabras sobre el incesto refuerza nuestra teoría de que el desconocimiento absoluto de los lazos de parentesco entre estas dos personas, anula el acto incestuoso, habiendo quedado demostrado además, que en la obra y el film, no es la causa de las penas del pueblo tebano, si no más bien un castigo mayor al propio Edipo por intentar oponerse a los dioses, y en consecuencia una condena sobre las dos personas más cercanas a éste, su padre Layo y su madre Yocasta. 
reflexión posterior, el descubrimiento de las pruebas de la verdadera relación entre Edipo y Yocasta, las que los llevan a cometer castigo sobre sí mismos.
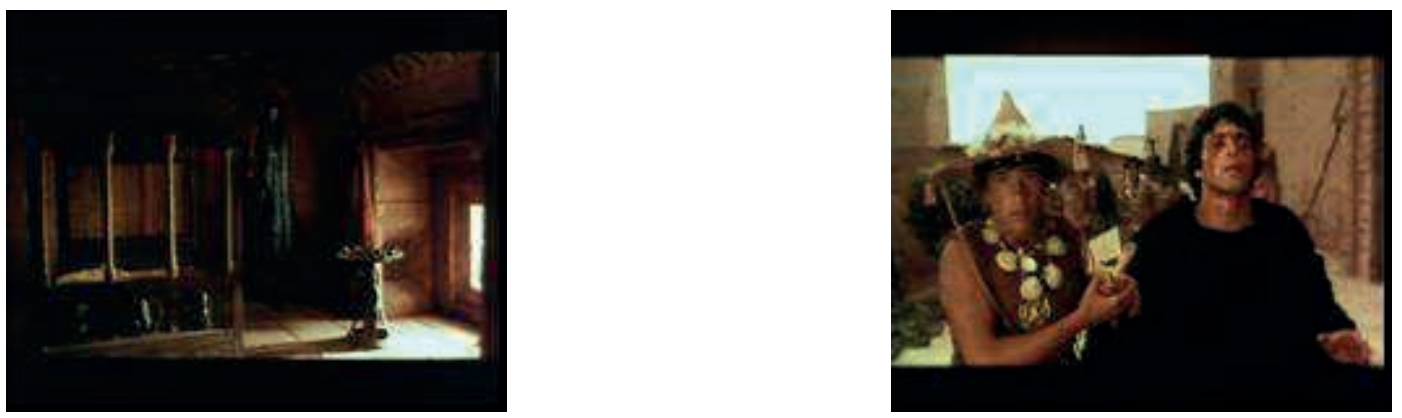

La mujer no puede perdonarse haber mantenido relaciones con el asesino de su marido, que además resulta ser su propio hijo, y decide suicidarse. El destino de Edipo corre parejo, pero se condena a vagar por el mundo ciego pero conocedor de la verdad de su destino, pues es el causante de la muerte de sus padres, uno a manos suyas, el otro de forma indirecta, además de haber compartido lecho con la que fuera su madre biológica.

Por ello se ve condenado a errar por el mundo ciego, pero en su oscuridad aún puede ver con claridad los acontecimientos que han marcado su vida. Y es entonces, al final de la vida de Edipo, cuando Pasolini nos devuelve a la época presente, para mostrarnos a un hombre que conocedor de su final, retorna al lugar donde comenzó su conciencia, para poner fin allí a su vida.
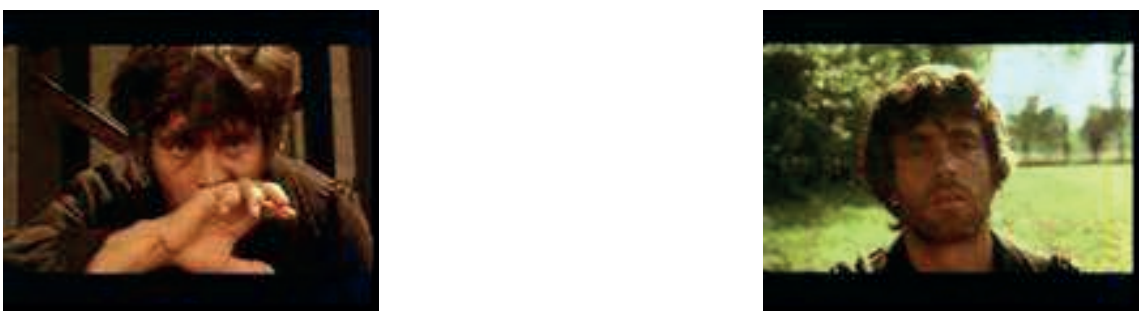
como un eterno retorno de lo otro" (Mariniello, pág. 287).

Los lazos de amor que unen a un hijo con su madre, pueden desencadenar actos muy diversos en función de quien los viva. El padre tiránico decide deshacerse el hijo, y el niño, ya condenado, llora por la ausencia de la madre, a quien termina retornando sin conocer su parentesco. El incesto en "Edipo Rey" sirve no solo como canto del amor que Pasolini profesaba por su madre, sino también como reflejo de que las pasiones dominan a los hombres muy por encima de su racionalidad. El acto sexual incestuoso, solo tiene lugar si este es consciente, el desconocimiento primero de Yocasta y Edipo los hace felices, son las circunstancias, el crimen sin respuesta de Layo, la peste que asola Tebas, las que terminan por destruir su relación, no sin antes, conocedores del acto incestuoso, se entregan a ello del mismo modo que en los encuentros anteriores daban rienda suelta a la pasión que como amantes se profesaban. El incesto, en el film de Pasolini, es una práctica que hace felices a sus protagonistas mientras desconocen su existencia, pero que les condena eternamente, solo a ellos, a un destino trágico señalado de antemano; unos designios divinos que no se deben contradecir, contra los que no se deben luchar, pues la idea que subyace en los dos textos edípicos, es que la felicidad humana siempre es caduca.

\section{Conclusiones}

La construcción social del incesto, más allá de la simple y mera definición de acto sexual practicado entre personas con una relación de parentesco previa basada en la consanguinidad o alianzas biológicas, posee dimensiones diversas que han ido evolucionando conjuntamente con el concepto a lo largo de los años. Estas dimensiones, algunos de cuyos aspectos hemos tratado de ver en el presente estudio, como los religiosos, mitológicos, antropológicos, sociales, éticos, morales o jurídicos 
ido otorgando al propio concepto un halo de tabú, prohibición, perversión, exotismo, erotismo, morbosidad, sexualidad, etc. que a día de hoy, en plena era post-moderna que tiende a convertir todo en un producto comercializable (y el sexo, y dentro de éste el sexo incestuoso, no escapa a su fuerza), nos es muy difícil definir con cierta exactitud el incesto, el acto sexual incestuoso, o al menos, con una cierta validez que podamos encontrar útil para poder afrontar un estudio sobre sus formas de ser representado a través del arte, y en nuestro caso, a través del cine.

Considerando estas dificultades, nos hemos propuesto una definición, y hemos mencionado algunos aspectos relacionados que deberíamos tener en cuenta, para poder realizar un análisis, quizás no tan pormenorizado como nos hubiera gustado, de algunas de sus formas de representación a través de tres de las obras cinematográficas más destacadas dentro de la historia del cine, donde el incesto, la relación amorosa y carnal existente entre madre e hijo (en los casos escogidos, pero existen muchas más formas de representación como pudieran ser entre padre e hija o entre hermanos) conformaba el núcleo centrar de la trama principal y su argumento o bien era una parte capital para el desarrollo de la historia.

Dichos análisis nos han hecho ver que, además de todos los aspectos previos, debíamos añadir las circunstancias personales que rodean al autor de las obras, así como su forma de ver e interiorizar el mundo en que le toco vivir cuando filmó la película y su forma de manifestar y reflexionar sobre el incesto y el mensaje o las cavilaciones que los espectadores podrían extraer del film mismo. Algo, que por otro lado, siempre es necesario incluir en un buen análisis narratológico (historia y discurso). 
casos que hemos visto, por los sentimientos que el director sienta o pudiera sentir hacía su madre (quizá, en otros casos de representación incestuosa entre padre e hija, este tipo de circunstancias no se hubieran dado), pero que en definitiva siempre enviará un mensaje de reflexión contemporáneo, a pesar de tomar como base el famoso mito edípico. Sirve, el mito descrito de forma trágica por Sófocles, a Pasolini, para construir un poema cinematográfico de amor a su madre, la persona que le insufló conciencia y cuyo amor terminará por dejarle ciego para poder ver con claridad un mundo condenado de antemano por epidemias que exigen siempre un culpable de cualquiera que fuera el crimen.

Hemos podido comprender, al menos desde nuestra perspectiva (que nunca será la única admisible o posible) que el mito de Edipo encierra una incógnita difícilmente explicable (al menos para poder convencer a todos), que no es otra que la planteada ya en su análisis, ¿podrían dos personas que desconocen su unión consanguínea estar cometiendo incesto?. El incesto ignorado no es un crimen en Edipo, como no lo sería en cualquier otra circunstancia ajena al vínculo que pudieran poseer los practicantes del acto sexual incestuoso. Es decir, si no se tiene conocimiento de que se está cometiendo incesto, ¿cómo es posible cometerlo? Intentando además, de forma voluntaria, alejarse de cometer dicho pecado, como el mismo Edipo hace cuando huye de Mérope y Pólibo.

El incesto, como toda la sexualidad, forma parte del ser humano y ha estado presente en su creación, en su evolución, y por muchos tabúes que podamos construir en torno a él, seguirá acompañándonos hasta el final de los tiempos, aunque sea solamente por medio de sus representaciones cinematográficas. 
FOX, Robin: "La lámpara roja del incesto". Fondo Cultural de Economía. México. 1990.

FREUD, Sigmund: “Tótem y tabú”. Alianza Editorial. Madrid. 1989.

LÉVI-STRAUSS, Claude: “Las estructuras elementales de parentesco". Paidos. Barcelona. 1991.

MARINIELLO, Silvestra: "Pier Paolo Pasolini". Cátedra, Signo e Imagen. Madrid. 1999.

MONCLUS, Antonio: “Pasolini: obra y muerte”. Fundamentos. Madrid. 1976.

PASOLINI, Pier Paolo: “Edipo Rey”. DVD. Distribuidora Filmax. 1967

SÓFOCLES: “Tragedias”. Biblioteca Clásica Gredos. Madrid. 1998

VVAA: "Después del incesto. Apoyo para la elaboración de las experiencias de incesto". Cuadernos Inacabados, Serie Salud, 14. Madrid. 1994.

VVAA: "La Santa Biblia”. Ediciones Paulinas. Madrid. 1989 